JSAP: Journal Syariah and Accounting Public

ISSN: 2622-3538

Available Online at https://journal.umgo.ac.id/index.php/JSAP/index

Vol. 4, No. 1 Juli 2021

DOI: $10.31314 /$ jsap.4.1.15-23.2021

\title{
ANALISIS PENERAPAN APLIKASI SISKEUDES DALAM MENINGKATKAN KUALITAS AKUNTABILITAS KEUANGAN DESA DI DESA HUYULA
}

\author{
Sry Anita Gusasi ${ }^{1}$, Felmi D. Lantowa ${ }^{2}$ \\ 1,2, Program Studi Akuntansi Fakultas Ilmu Sosial Universitas Muhammadiyah Gorontalo \\ Email; anitagusasi.sry@gmail.com, felmilantowa@umgo.ac.id
}

Info Artikel: Diterima: 13 Nov. 2019, Disetujui: 17 Februari 2020, Publish 15 Juli 2021

\begin{abstract}
:
This research aims to first analyze the management of the SISKEUDES application and analyze the application of the SISKEUDES application in improving the quality of village financial accountability in Huyula Village, Mootilangosub-district, Gorontalo regency. This research uses descriptive research with a qualitative approach. . Collecting data used descriptive research and qualitative approach The result of this research is that the management of the SISKEUDES application in Huyula Village, Mootilango sub-district, Gorontalo regency has carried out an accountability process according to established procedures. Huyula Village has also implemented the principle of obedience and obedience in carrying out duties and responsibilities. For the quality of financial accountability in Huyula Village, after the implementation of the SISKEUDES application, it brought quite a good change for the Huyula Village government, namely making it easier to report accurate accountability so as to produce transparent and accountable financial reports.
\end{abstract}

Keywords: SISKEUDES, Accountability, Finance

Abstrak:

Penelitian ini bertujuan untuk menganalisis pengelolaan aplikasi SISKEUDES dan menganalisis penerapan aplikasi SISKEUDES dalam meningkatkan kualitas akuntabilitas keuangan desa di Desa Huyula Kecamatan Mootilango Kabupaten Gorontalo. Penelitian ini menggunakan jenis penelitian deskriptif kualitatif dengan pendekatan kualitatif. Pengumpulan data menggunakan metode wawancara dan observasi awal. Hasil penelitian menunjukan pengelolaan aplikasi SISKEUDES di Desa Huyula Kecamatan Mootilango Kabupaten Gorontalo telah melakukan proses pertanggungjawaban sesuai prosedur yang ditetapkan dan sudah menerapkan prinsip patuh serta taat dalam melaksanakan tugas dan tanggungjawab. Penerapan aplikasi SISKEUDES sangat membawa perubahan yang cukup baik bagi pemerintah Desa huyula, yaitu mempermudah dalam pelaporan pertanggungjawaban yang akurat sehingga menghasilkan laporan keuangan yang transparan dan akuntabel.

Kata kunci : SISKEUDES, Akuntabilitas, Keuangan

$\begin{array}{cc}\text { PENDAHULUAN } & \text { transparansi dan akuntabilitas dalam } \\ \text { Tata kelola pemerintah yang baik } & \begin{array}{c}\text { pengelolaan pemerintahan. } \\ \text { merupakan salah satu tuntutan masyarakat }\end{array} \\ \begin{array}{c}\text { Tuntutan akuntabilitas ini berlaku untuk } \\ \text { pemerintahan yang baik adalah adanya }\end{array} & \text { karena dari desalah yang menjadi unsur }\end{array}$

JSAP: Journal Syariah and Accounting Public, Vol. 4, No. 1 Juli 2021 
pelaksana kegiatan yang bersentuhan langsung dengan masyarakat. Untuk memperkuat otonomi desa ini maka pemerintah menerbitkan peraturan pemerintah untuk pengaturan desa yakni UU Nomor 6 Tahun 2014 tentang Desa yang merupakan suatu tonggak baru dalam sistem otonomi desa. Dalam UU ini desa diberi otorisasi yang luas dalam mengelola tata pemerintah sendiri serta termasuk dalam pelaksanaan pembangunan desa untuk peningkatan kualitas hidup dan kesejahteraan masyarakatnya. Selain itu, pemerintah desa diberi keleluasaan untuk mengelola keuangan dan kekayaan milik desa. Penerimaan dana oleh pemerintah desa tentunya akan berdampak pada tuntutan tanggungjawab pengelolaan tersebut dari pengelola.

Pemerintah desa diwajibkan untuk menyusun Laporan Realisasi pelaksanaan Anggaran Penerimaan dan Belanja (APB) Desa serta Laporan Pertanggung Jawaban Realisasi Pelaksanaan APB Desa. Laporan hasil pengelolaan keuangan desa merupakan sebuah bentuk pertanggungjawaban kinerja terhadap masyarakat sesuai dengan Permendagri No. 113 Tahun 2014 mengenai Pedoman Pengelolaan Keuangan Desa. Maka dengan ini Pemerintah bersama Kementrian dalam Negeri dan Badan Pengawasan Keuangan dan Pembangunan (BPKP) mendorong akuntabilitas pengelolaan keuangan desa dengan mengembangkan tata kelola keuangan melalui Aplikasi Sistem Keuangan Desa (SISKEUDES).

Aplikasi SISKEUDES merupakan aplikasi yang dikembangkan BPKP dalam rangka meningkatkan kualitas tata kelola keuangan desa. Salah satu Desa yang telah mengaplikasikan SISKEUDES yakni Desa Huyula Kecamatan Mootilango Kabupaten Gorontalo.
Berikut ini gambaran terkait SISKEUDES yang digunakan oleh Desa Huyula Kecamatan Mootilango Kabupaten Gorontalo:

Gambar 1. Aplikasi Sistem Keuangan Desa

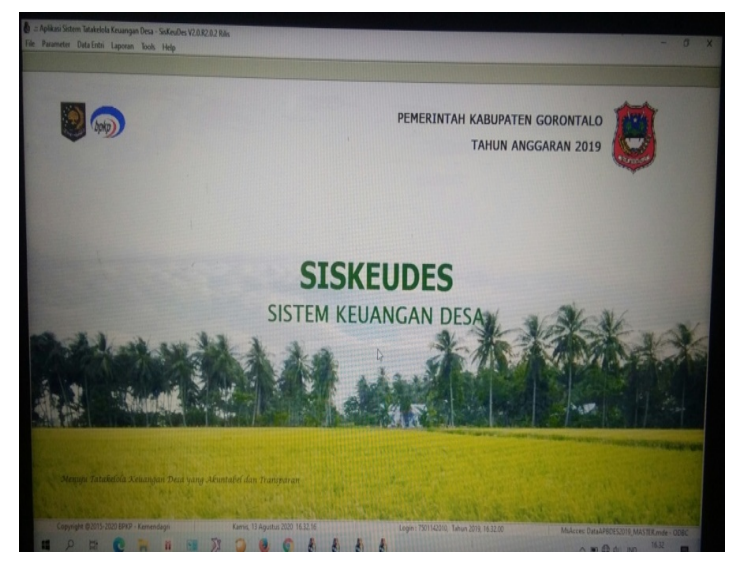

Sumber: Sistem Keuangan Desa Pemerintah

Kabupaten Gorontalo, 2020

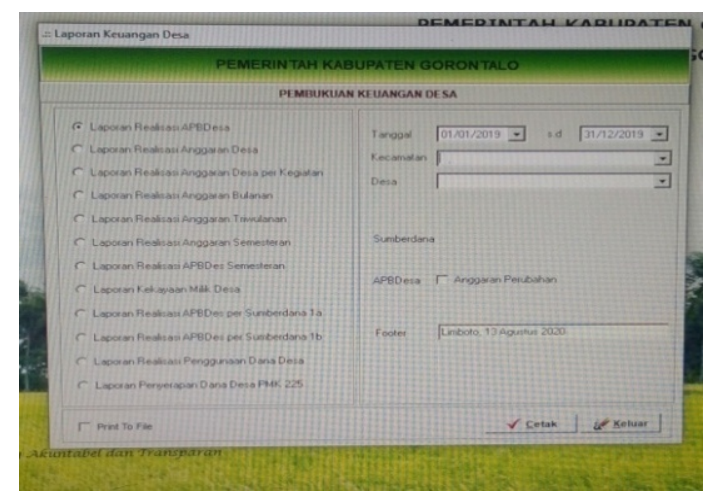

Gambar 2. Laporan Keuangan desa

Sumber : Sistem Keuangan Desa Pemerintah Kabupaten Gorontalo, 2020

Desa Huyula Kecamatan Mootilango Kabupaten Gorontalo menurut gopost.id,Limboto (2020) menjadi salah satu desa yang mendapat perhatian dari pemerintah Kabupaten Gorontalo. Terbukti dalam dua tahun terakhir ini, ada 103 unit rumah layak huni yang dibangun Pemerintah Daerah untuk warga Desa Huyula selain itu desa ini juga merupakan desa yang telah menerapkan SISKEUDES sejak 2016 setelah dilakukan launching pada 13 Juli 
2015. Sesuai dengan hasil wawancara awal yang dilakukan dengan bendahara desa mengatakan bahwa SISKEUDES sangat membantu dalam pelaporan keuangan namun masih terdapat kendala yang mereka hadapi terkait aturan SISKEUDES yang berubah-ubah dari pemerintah kabupaten ke desa yang agak lama karena jaringan internet yang kurang memadai, serta versi SISKEUDES yang berubah-berubah sejak pertama kali diterapkan pada tahun 2016. Hal ini membuat pelaporan keuangan yang berubah-ubah misalnya akun transaksi terkait Program Keluarga Harapan (PKH) dan posyandu masuk pada akun pemberdayaan, setelah dilaporkan akan masuk pada akun operasional pada SISKEDES sehingga hal ini menjadi kendala dalam pelaporan pertanggungjawaban keuangan desa.

Berdasarkan latar belakang tersebut dapat dirumuskan masalah sebagai berikut :

1. Mekanisme atau aturan pelaporan keuangan melalui siskeudes yang berubah-ubah setiap tahunnya terutama terkait dengan penempatan akun.

2. Lambatnya Informasi terkait aturan SISKEUDES dari Pemerintah Kabupaten ke desa yang diakibatkan karena jaringan internet yang kurang memadai.

Adapun yang menjadi tujuan penelitian ini adalah sebagai berikut :

1. Untuk menganalisis Pengelolaan Aplikasi SISKEUDES di Desa Huyula Kecamatan Mootilango Kabupaten Gorontalo.

2. Untuk menganalisis Penerapan Aplikasi SISKEUDES dalam Meningkatkan kualitas Akuntabilitas Keuangan Desa, di Desa Huyula Kecamatan Mootilango Kabupaten Gorontalo.

\section{METODE PENELITIAN}

Jenis penelitian yang digunakan dalam penelitian ini adalah jenis penelitian deskriptif dengan pendekatan kualitatif yaitu metode penelitian yang berlandaskan filsafat postpositivisme, digunakan untuk meneliti pada kondisi obyek yang alamiah. Teknik pengumpulan data yang digunakan dalam metode studi lapangan ini menggunakan tiga cara yaitu studi kepustakaan, pengamatan/ observasi dan wawancara langsung.

\section{HASIL DAN PEMBAHASAN}

$\begin{array}{lcr}\text { Penelitian } & \text { bertujuan } & \text { untuk } \\ \text { menganalisis } & \text { penerapan } & \text { aplikasi } \\ \text { SISKEUDES dalam meningkatkan } & \text { kualitas }\end{array}$ akuntabilitas keuangan desa, di Desa Huyula Kecamatan Mootilango Kabupaten Gorontalo. Dalam penelitian ini peneliti menggunakan indikator akuntabilitas menurut dadang solihin yang terdiri dari beberapa indikator diantaranya:

a) Adanya kesesuaian antara pelaksanaan dengan prosedur standar pelaksanaan.

b) Adanya sanksi yang ditetapkan atas kesalahan atau kelalaian dalam pelaksanaan kegiatan.

c) Adanya output dan outcome yang terukur.

Hasil penelitian yang dilakukan melalui observasi, wawancara dan dokumentasi dapat dideskripsikan sebagai berikut :

1. Adanya kesesuaian antara pelaksanaan dengan prosedur standar pelaksanaan.

Hasil wawancara peneliti dengan Kepala Desa menyatakan bahwa:

"Sistem keuangan desa di desa huyula sudah berjalan sesuai prosedur yang ditetapkan, dilihat dari pelaporan yang dibuat oleh pengelola aplikasi sistem keuangan desa itu sendiri karena jika suatu laporan tidak sesuai prosedur maka laporan tersebut tidak akan diterima, akan tetapi masih ada kendala yang kami hadapi terkait aturan 
SISKEUDES yang sering ada perubahan. " (wawancara, IN tanggal 02/10/2020 pukul 09.25 Wita).

2. Adanya sanksi yang ditetapkan atas kesalahan atau kelalaian dalam pelaksanaan kegiatan.

Hasil wawancara peneliti dengan Kaur Keuangan Desa menyatakan bahwa:

"Kalau kesalahan atau kelalaian dapat merugikan banyak pihak pasti ada sanksinya yaitu sanksi administrasi atau sanksi pidana secara umum yang diatur Undang-Undang Nomor 1 Tahun 2004 tentang perbendaharaan Negara. Tetapi kalau dalam proses menjalankan aplikasi siskeudes bila mana ada salah satu nama akun yang tidak sesuai di input maka akan valid pada sistem itu sendiri " (wawancara, RM tanggal 01/10/2020 pukul 09.15 Wita).

3. Adanya output dan outcome yang terukur.

Hasil wawancara peneliti dengan Sekretaris Desa menyatakan bahwa:

"output dari aplikasi SISKEUDES ini merupakan laporan keuangan desa, dengan adanya aplikasi SISKEUDES pemerintah desa sangat terbantu dalam mengelola keuangan maupun anggaran desa dan terencana dengan baik" (wawancara, RY tanggal 01/10/2020 Pukul 10.25 Wita).

Sebagaimana yang menjadi fokus penelitian yang telah digambarkan dari penelitian diatas di fokuskan pada bagaimana pengelolaan aplikasi SISKEUDES di Desa Huyula Kecamatan Mootilango Kabupaten Gorontalo, dan bagaimana analisis penerapan aplikasi SISKEUDES dalam meningkatkan kualitas akuntabilitas keuangan Desa di Desa Huyula Kecamatan Mootilango Kabupaten Gorontalo.

1. Adanya kesesuaian $\begin{array}{r}\text { antara } \\ \text { pelaksanaan dengan } \\ \text { standard }\end{array}$
prosedur pelaksanaan.

Standard prosedur pelaksanaan merupakan suatu pedoman atau acuan untuk melaksanakan tugas pekerjaan sesuai dengan fungsi dan alat penilaian kinerja instansi pemerintah maupun nonpemerintah. Menurut penjelasan menteri pendayagunaan aparatur Negara (permenpan No.PER/21/M-PAN/11/2008), manfaat SOP secara umum bagi organisasi adalah :

a) Sebagai standarisasi cara yang dilakukan pegawai dalam menyelesaikan pekerjaan khusus, mengurangi kesalahan dan kelalaian.

b) SOP membantu staf menjadi lebih mandiri dan tidak tergantung pada intervesi manajemen, sehingga akan mengurang keterlibatan pimpinan dalam pelaksanaan proses sehari-hari.

c) Meningkatkan akuntabilitas dengan mendokumentasikan tanggungjawab khusus dalam melaksanakan tugas.

d) Menciptakan ukuran standard kinerja yang akan memberikan pegawai cara konkret untuk memperbaiki kinerja serta membantu mengevaluasi usaha yang telah dilakukan.

e) Menciptakan bahan-bahan training yang dapat membantu pegawai baru utnutk cepat melakukan tugasnya.

f) Menunjukkan kinerja bahwa organisasi efisien dan dikelola dengan baik.

g) Menyediakan pedoman bagi setiap pegawai di unit pelayanan dalam melaksanakan pemberian pelayanan sehari-hari.

h) Menghindari tumpang tindih pelaksanaan tugas pemberian pelayanan

i) Membangtu penelusuran terhadap kesalahan-kesalahan procedural dalam memberikan pelayanan. Menjamin proses pelayanan tetap berjalan dalam berbagai situasi. 
Berdasarkan hasil observasi awal yang ditemui peneliti di Desa Huyula Kecamatan Mootilango Kabupaten Gorontalo bahwa standard prosedur pelaksanaan SISKEUDES berubah-ubah setiap tahunnya sehingga menyebabkan keuangan desa tidak maksimal.

Kemudian berdasarkan keseluruhan hasil wawancara dan analisis peneliti, peneliti menemukan bahwa di Desa Huyula Kecamatan Mootilango sudah sesuai dengan standard operasional pelaksanaan SISKEUDES, namun diakibatkan oleh lambatnya informasi tentang aturan terkait SISKEUDES dikarenakan jaringan yang kurang memadai membuat laporan keuangan desa tidak maksimal. Hal ini sejalan dengan teori yang dikemukakan oleh Malahika 2018 dalam jurnal "Penerapan Sistem Keuangan Desa (SISKEUDES) Pada Organisasi Pemerintahan Desa (Studi Kasus Di Desa Suwaan Kecamatan Kalawat Kabupaten Minahasa utara)" yang menyatakan bahwa penerapan aplikasi SISKEUDES sejauh ini sudah berjalan dengan baik. Prosedur-prosedur penggunaan SISKEUDES pun sudah dilakukan sesuai dengan peraturan yang berlaku. Menu-menu di aplikasi SISKEUDES pun dibuat dengan sedemikian rupa sesuai dengan prosedur Pengelolaan Keuangan Desa. Dimulai dari tahap Perencanaan, Pelaksanaan, Penatausahaan, dan Pelaporan. Penggunaan SISKEUDES tentunya tidak luput dari beberapa kendala dimana masih ada beberapa laporan yang belum input ke sistem, hal ini mungkin terjadi karena SISKEUDES sering mengalami error atau jaringan yang kurang memadai, ada baiknya para pegawai berusaha untuk melakukan koordinasi antar pegawai dan pendamping desa untuk dapat memaksimalkan pekerjaan sehingga mampu mengatasi masalah yang terjadi.
Dari uraian diatas melalui observasi dan keseluruhan wawancara serta hasil analisis peneliti maka dapat disimpulkan bahwa dilihat dari adanya kesesuaian antara pelaksanaan dengan standard prosedur pelaksanaan, pengelolaan Keuangan di Desa Huyula Kecamatan Mootilango telah dilaksanakan dengan baik dan sesuai prosedur yang ditetapkan akan tetapi dari segi standar operasional prosedur yang dikeluarkan oleh pemerintah yang sering berubah-ubah dan jaringan yang kurang memadai masih menjadi kendala bagi desa dalam pengelolaan keuangan desa pada aplikasi SISKEUDES.

2. Adanya sanksi yang ditetapkan atas kesalahan atau kelalaian

Pengelola keuangan desa harus dipercayakan kepada pengelola yang memiliki integritas dan kejujuran yang tinggi karena akuntabilitas yang secara umum adalah pertanggungjawaban atas amanah yang telah diberikan. Sehingga dengan adanya aplikasi SISKEUDES ini aparat pemerintah desa dapat memberikan peran untuk meminimalisir tindakan kecurangan atau kelalaian dengan adanya sumber daya manusia yang memiliki integritas dan kejujuran yang tinggi serta tujuan yang bisa dipertanggungjawabkan akuntabilitasnya.

Berdasarkan hasil observasi awal yang dilakukan oleh peneliti di Desa Huyula Kecamatan Mootilango bahwa terdapat sanksi jika terdapat kesalahan dalam penginputan laporan keungan pada aplikasi SISKEUDES.

Kemudian berdasarkan keseluruhan hasil wawancara serta hasil analisis peneliti bahwa peneliti menemukan bahwa jika pemerintah desa tidak menggunakan Aplikasi SISKEUDES maka anggaran tidak dicairkan. Hal ini konsisten dengan Undang Undang nomor 6 tahun 2014 tentang Desa 
dalam penjelasan pasal 24 huruf g yang menyatakan bahwa akuntabilitas adalah asas yang menentukan bahwa setiap kegiatan penyelenggaraan pemerintah desa harus dapat dipertanggungjawabkan kepada masyarakat desa sesuai ketentuan perundang undangan.

Dari uraian diatas melalui observasi awal dan keseluruhan hasil wawancara serta hasil analisis peneliti maka dapat disimpulkan bahwa Pemerintah Desa Huyula Kecamatan Mootilango Kabupaten gorontalo sudah berupaya memaksimalkan penggunanaan Aplikasi SISKEUDES dalam pelaporan keuangan desa karena jika pemerintah desa tidak memaksimalkan penggunaan aplikasi tersebut akan berdampak pada proses pencairan anggaran.

3. Adanya output dan outcome yang terukur

Output adalah hasil yang di dapat langsung satu serangkaian aktivitas telah dilakukan, sedangkan outcome merupakan hasil atau manfaat yang dirasakan dari suatu aktivitas.

Berdasarkan hasil observasi awal yang dilakukan oleh peneliti di Desa Huyula Kecamatan Mootilango menemukan bahwa dengan adanya aplikasi SISKEUDES pemerintah desa lebih mudah dalam membuat laporan keuangan desa.

Kemudian berdasarkan keseluruhan hasil wawancara peneliti serta hasil analisis, peneliti menemukan bahwa aplikasi SISKEUDES membantu kinerja pemerintah desa dalam mengelola keuangan desa, sehingga pemerintah desa dapat meningkatkan kualitas akuntabilitas keuangan desa. Hal ini konsisten dari peneliti terdahulu Muhammad Anur Ridwan tahun 2019, dimana hasil penelitian ini menunjukan bahwa untuk pengelolaan aplikasi SISKEUDES di Desa Bogorejo sudah terstruktur dengan baik dan memenuhi standar penerapan serta melakukan proses pertanggungjawaban yang relevan, sehingga semua proses pengelolaan sudah baik. Aplikasi SISKEUDES ini juga sangat membawa perubahan yang baik di Desa Bogorejo, karena mempermudah dalam pelaporan pertanggungjawaban, menghasilkan laporan keuangan yang akurat, relevan dan mampu menyajikan laporan keuangan dengan wajar sesuai dengan Peraturan Pemerintah No. 24 Tahun 2005, sehingga dengan penerapan aplikasi sistem keuangan desa mampu berperan dalam meningkatkan kualitas akuntabilitas keuangan desa dalam rangka mewujudkan tata kelola keuangan desa yang baik.

Dari uraian diatas melalui observasi awal dan keseluruhan wawancara serta hasil analisis peneliti maka dapat disimpulkan bahwa dengan adanya aplikasi SISKEUDES pemerintah desa lebih mudah mengelola keuangan desa sehingga dapat menghasilkan laporan keuangan yang akuntabel..

\section{KESIMPULAN}

Pengelolaan aplikasi SISKEUDES di
Desa Huyula Kecamatan
Pengelolaan aplikasi SISKEUDES di
Desa Huyula Kecamatan Mootilango Kabupaten Gorontalo telah melakukan proses pertanggungjawaban sesuai prosedur yang ditetapkan dan dalam menjalankan aplikasi tersebut sudah terstruktur dengan baik akan tetapi dari segi standar operasional prosedur yang dikeluarkan oleh pemerintah yang sering berubah-ubah dan jaringan yang kurang memadai masih menjadi kendala bagi desa dalam penerapan aplikasi SISKEUDES. Desa Huyula juga sudah menerapkan prinsip dan tanggungjawab. Untuk kualitas 
akuntabilitas keuangan di Desa Huyula setelah penerapan aplikasi SISKEUDES sangat membawa perubahan yang cukup baik bagi pemerintah Desa huyula, yaitu mempermudah dalam pelaporan pertanggungjawaban yang akurat dan menghasilkan laporan keuangan yang transparan dan akuntabel.

\section{SARAN}

Berdasarkan hasil penelitian dan kesimpulan yang telah diuraikan di atas, maka saran penelitian ini sebagai berikut :

Pihak Pemerintah

Diharapkan kepada pihak pemerintah agar menetapkan aturan terkait standar prosedur penerapan SISKEUDES sehingga pemerintah desa dapat menguasai sistem yang ada.

Pihak Masyarakat

Diharapkan kepada masyarakat sebiknya lebih mendukung dalam program pemerintah desa.

Bagi Peneliti Selanjutnya

Bagi peneliti selanjutnya yang akan meneliti tentang Penerapan Aplikasi Siskeudes Dalam Meningkatkan Kualitas Akuntabilitas Keuangan Desa disarankan agar lebih mendalami kajian penelitiannya..

\section{REFERENSI}

Dwi Ratmono dan Mahfud Sholihin. 2015. Akuntansi Keuangan Daerah Berbasis Akrual. Edisi Pertama.Yogyakarta : UPP STIM YKPN.

Mahmudi. 2011. Akuntansi Sektor Publik. Yogyakarta: UII Pres.

Mardiasmo. 2018. Akuntansi Sektor Publik. Yogyakarta: Andi Yogyakarta.

Sugiyono 2016. Memahami penelitian kualitatif. Bandung: ALFABETA
Anur Ridwan, 2019. Analisis Peran Aplikasi Sistem Keuangan Desa (Siskeudes) Dalam Meningkatkan Kualitas Akuntabilitas Keuangan Desa Di Tinjau Dari Perspektif Ekonomi Islam.

Gusti Ayu Trisha Sulina tahun 2017, Peranan Sistem Keuangan Desa (Siskeudes) Terhadap Kinerja Pemerintah Desa (Studi Kasus di Desa Kaba-kaba, Kecamatan Kediri, Kabupaten Tabanan)

Jehan M. Malahika, 2018. Penerapan Sistem Keuangan Desa (Siskeudes) Pada Organisasi Pemerintahan Desa (Studi Kasus Di Desa Suwaan Kecamatan Kalawat Kabupaten Minahasa Utara).

Muhammad Sapril Sardi Juardi, 2018. Evaluasi Penggunaan Aplikasi SISKEUDES Dalam Upaya Peningkatan Kualitas Akuntabilitas Keuangan Desa (Studi Pada Desa Jenetallasa Kec. Pallangga Kab. Gowa).

Oktaviani Rita Puspasari, 2018. Implementasi Sistem Keuangan Desa Dan Kualitas Laporan Keuangan Pemerintah Desa Di Kabupaten Kuningan.

Ramadhan 2014. Dalam jurnal Oktaviani Rita Puspasari. dengan judul Implementasi Sistem Keuangan Desa Dan Kualitas Laporan Keuangan Pemerintah Desa Di Kabupaten Kuningan.

Peraturan pemerintah Nomor 71 Tahun 2010 tentang Standar Akuntansi Pemerintahan.

Peraturan Kementrian Dalam Negeri Republik Indonesia Nomor 113 (Permendagri Nomor 113 Tahun 2014) Tentang Pengelolaan Keuangan Desa.

Peraturan Menteri Dalam Negeri Nomor 20 Tahun 2018 tentang Pengelolaan Keuangan Desa, Pasal 1 ayat (5)

Peraturan Menteri Dalam Negeri Nomor 20 Tahun 2018 tentang Pengelolaan Keuangan Desa, Pasal 1 ayat (6)

$\begin{array}{rcr}\text { Permen PAN } & \text { Nomor: } & \text { PER/21/M- } \\ \text { PAN/11/2008 } & \text { tentang } & \text { Pedoman }\end{array}$ 
Penyusunan Standar Operasional Prosedur Administrasi Pemerintahan

Undang Undang Nomor 6 Tahun 2014 tentang Desa.

Gorontalo Post. 2020. Bupati Puji Kades Huyula Pandai Bahagiakan Warganya. https://gopost.id/berita/bupati-pujikades-huyula-pandai-bahagiakanwarganyal. (diakses 13 Agustus (2020).

Situs Resmi Badan Pengawasan Keuangan \& Pembangunan. 2020. Sejarah Aplikasi Sistem Keuangan Desa.

http://www.bpkp.go.id/sakd/konten/2448/Leaf let-Simda-Desa.bpkp (diakses 12 Agustus 2020). 